\title{
Erratum to: Plant Posters
}

\author{
Society for In Vitro Biology
}

Published online: 18 November 2016

(C) The Society for In Vitro Biology 2016

Erratum to: In Vitro Cell.Dev.Biol._Animal (2016) 52

(Suppl 1):S52-S73

DOI 10.1007/s11626-016-0035-Z

\section{Plant Posters}

The name of Carola Ledderose is incorrectly listed on SpringerLink and should be deleted. 